\title{
The Importance of Think Talk Write Learning Model on the Mathematical Connection Ability and Self-Confidence
}

\author{
*Muhamad Afandi1, Dede Ainun Nisa ${ }^{2}$, Rida Fironika Kusumadewi ${ }^{3}$
}

${ }^{123}$ Elementary School Teacher Education Study Program, Sultan Agung Islamic University, Semarang, Indonesia

A R T I C L E I N F O

Article history:

25 December 2020

Received in revised form

01 January 2021

Accepted 25 January 2021

Available online 03

Pebruari 2021

Kata Kunci:

Koneksi Matematis,

Percaya Diri, Model Think

Talk Write

Keywords:

Mathematical Connection Ability, Confidence Attitude,

Think Talk Write

\begin{abstract}
A B S T R A K
Penggunaan model pembelajaran yang monoton dan kurang menarik mengakibatkan konektivitas dan sikap kepercayaan diri rendah. Penelitian ini bertujuan guna melihat pengaruh model pembelajaran TTW pada kemampuan koneksi matematis serta sikap percaya diri peserta didik materi pecahan kelas IV. Penelitian ini dilakukan pada siswa kelas IV. Metode penelitian ini adalah penelitian kuantitatif dengan desain penelitian Quasi Experimental Design pada bentuk Nonequivalent Control Group Design. Teknik pengumpulan data melalui tes dan angket. Analisis data menggunakan uji normalitas, uji homogenitas dan uji hipotesis. Hasil penelitian membuktikan : (1) Ada pengaruh model pembelajaran TTW pada kompetensi koneksi matematis, yang ditunjukkan melalui hasil uji Independent Sample TTest ada nilai Sig. (2-tailed) 0,038< 0,05 artinya Ho tak diterima serta Ha diterima serta dalam uji Paired Sample T-Test nilai Sig. (2-tailed) $0,000<0,05$ berarti Ho tak diterima serta Ha diterima.(2) Ada pengaruh model pembelajaran TTW pada sikap percaya diri, dari perhitungan
\end{abstract} Independent ada hasil Sig. (2-tailed) $0,000<0,05$ artinya Ho ditolak serta Ha diterima dan dalam Paired hasil Sig. (2-tailed) $0,000<0,05$ berarti Ho ditolak serta $\mathrm{Ha}$ diterima. Penelitian ini mengimplikasikan bahwa model pembelajaran TTW dapat meningkatkan kemampuan koneksi matematis dan sikap percaya diri siswa materi pecahan kelas IV.

\section{A B S T R A C T}

The use of a monotonous and less attractive learning model results in low connectivity and low confidence. The purpose of this study was to determine the effect of the Think Talk Write (TTW) learnng model on the mathematical connection ability and self-confidence students class IV fraction material. The formulation of the problem in this study is wether there is an effect of the Think Talk Write learning model on the mathematical connection ability and self-confidence students class IV fraction material. This research is conducted to students class IV. This study is a quantitative research with Quasi Experimental Design in the form Nonequivalent Control Group Design. Data collection techniques method the test and questionnaries. Data analysis uses normality test, homogeneity test and hypothesis test. The results show that: 1) There is an effect of the Think Talk Write learning model on the mathematical connection ability, as evidenced by the results of the Independent Sample $T$ Test, there is a sig. (2-tailed) $0.038<0.05$ then Ho is rejected and Ha is accepted in the Paired Sample T-Test there is a sig. (2-tailed) $0.000<0.05$ then Ho is rejected and Ha is accepted. 2) There is an influence of the Think Talk Write learning model on self-confidence from the independent calculation there is a sig. (2-tailed) $0.000<0.05$ means that Ho is rejected and Ha is accepted, while in Paired the results are Sig. (2-tailed) $0.000<0.05$ means that $\mathrm{Ho}$ is rejected and $\mathrm{Ha}$ is accepted. This research implies that the TTW learning model can improve the mathematical connection ability and selfconfidence students class IV fraction material. 


\section{Introduction}

Mathematics is a science that is related to student life. Through studying and understanding various mathematical concepts, students will be able to solve a number of life problems related to mathematics. Mathematics according to (Wirdah et al., 2014;Hasratuddin, 2013) suggests that learning mathematics is a good thinking school about how to solve problems both practical and abstract problems so that students can develop their ability to solve problems later. In the world of education, mathematics has been introduced to children when they enter kindergarten until college. Except that the activities we do in everyday life are closely related to mathematics.

Based on observations made at elementary schools in Petarukan sub-district, information was obtained about learning mathematics, namely students considered that learning mathematics was difficult and complicated because it was related to counting numbers and formulas, the low ability of mathematical connections was caused by students who thought they did not know the connectivity between mathematics with everyday life as well as with other materials or concepts, teachers still use conventional models and students have low self-confidence.

Students' mathematical connection abilities cannot develop on their own, but they need to be guided in developing these abilities. Therefore, connection to learning mathematics really needs to be apllied in schools, Wahyuni in (Anita, 2014) argues that there are three objectives of mathematical connections in schools according to NCTM, namely broadening that knowledge of students, mathematics as an integrated whole not independent material has relevance and benefits bots at school and outside of school. Connestion skills also need to be developed by providing mathematical problems that are solved using mathematical connections and creating student-oriented learning where the teacher only guides students to find mathematical concepts themselves. Connection requires students to be able to show and relate mathematical relationships with other studies or daily life so that students can solve math problems (Muna et al., 2020). Meanwhile (Haji et al., 2017) argued mathematical connections about the understanding of students in connecting mathematical ideas that will facilitate the ability to formulate and verify the assumptions between topics deductively. This means that the mathematical connection discusses students' understanding in connecting mathematical ideas, formulating and verifying environmental assumptions between topics in a deductive way. According to (Nurapriani, 2016), thinking talk write learning was recognized as having an effect on the mathematical connection ability of students which can be seen from the results of the N-Gain value of 0.1488 which was greater than using the model. conventional learning with an N-Gain value of 0.073299 . This study shows that mathematical connection skills are required to have a high level of ability.

In the learning process, the role of students is only listening and paying attention to the teacher's explanation. Conventional learning is carried out on students turns out to cause problems of low selfconfidence because they do not actively ask questions and hesitate in expressing their opinions. In addition, most students do not pay attention to the teacher's explanation so that it has an impact on students' self-confidence. A self-confidence attitude can train students to be mpre confident in linking mathematics with real life and with other mathematical concept or topics. Self-confidence according to Saputra with (Melyana et al., 2020) is one of the successes of students in learning, because without selfconfidence students will not interact with their friends. Based on students' self-confidence problems using think talk write learning is very effective because in the learning process students are expected to be confident and bold in conveying ideas or ideas. According to (Trisnawati et al., 2018) self-confidence is a positive attitude of an individual which enables him to develop positive judgment and already understands the strengths and weaknesses that are formed and learned through the learning process, According to research (Khoerunnisa, et.al, 2016) with the title of the effectiveness of think talk writing learning assisted by independent teaching aids on mathematical communication and self-confidence of grade VII students. It was found that students' self-confidence was greater than using conventional learning. In this study, self-confidence can be formed from habits so that it should be accustomed to become the character of students and in the learning process of students being much more active.

Based on all the conditions that have been described, one of the efforts that can be carried out in the learning process is specifically to improve the competence of marematic connections and students' confident attitudes, student-oriented learning, where the teacher only guides students to be able to find their own mathematical concepts being taught,namely learning that can encourage students to know the function of the material being discussed, facilitate the needs of students to collaborate and discuss with his group mates. According to (Supandi et.al, 2018), the use of learning models can improve students in developing ideas and solving math problems. Therefore, the appropriate learning model to increase the competence of mathematical connections and students' self-confidence uses the Think Talk Write model. 
The think talk write model is learning that begins with thinking through reading and the results are communicated with presentations, discussions, and making reports on the results of presentations (Hamdayana, 2014). Think talk write learning also involves students in thinking or having dialogue with themselves through reading, talking (talk) and sharing ideas with friends before writing (Husna, 2016). Based on this, of course at the reading stage, students will be trained in their thinking skills by connecting mathematics learning with daily life as well as with other mathematical material theories and in the process of conveying opinions, students can train self-confidence. This model has advantages that can develop students 'skills such as being responsible, confident, analyzing, and writing various ideas of students (Lismawati, 2019). In this study, the think talk write learning model is used because it provides opportunities for students to understand the learning material and be able to solve the questions delivered by the teacher individually. At the talk stage (speaking), it provides the opportunity for students to ask questions and express their opinions or ideas in writing and at the write stage (writing), it provides opportunities for students to express their ideas or opinions in writing. Thus, this study explores the importance of the Think Talk Write learning model on the mathematical connection ability and selfconfidence of students in grade IV especially for fraction material.

\section{Method}

This study is a quantitative research using a quasi-experimental method and the Nonequivalent Control Group Design. The design uses an experimental class and a control class starting with a pretest given to both groups, then given treatment. Furthermore, this study ends with a final test (posttest) given to both classes. In the experimental class, it was treated by applying the Think Talk write learning model while in the control class it was not treated using the think talk write model but with the conventional learning model. The following is a drawing of the design scheme used by (Sugiyono, 2017), namely:

Table 1. Research Design

\begin{tabular}{lll}
\hline $\mathrm{O}_{1}$ & $\mathrm{X}$ & $\mathrm{O}_{2}$ \\
$\mathrm{O}_{3}$ & & $\mathrm{O}_{4}$ \\
\hline
\end{tabular}

The experimental class pretest (01) is given the think talk write (X) learning model treatment. It will affect the posttest experimental class (02). The control class pretest (03) used conventional learning models and was carried out by the control class posttest (04).

The subjects of this study were fourth grade students of SD Negeri 01 and 03 Kalirandu with a sample of 52 students taken from 26 students of State Elementary School of 01 Kalirandu and 26 students of State Elementary school of 03 Kalirandu. This sample was selected using simple random sampling technique (Sugiyono, 2017).

Mathematical connection ability test data were collected using a multiple choice test method while self-confidence was collected using questionnaires. The instruments will be validated first to find out the validity and reliability of the measuring instrument. The measuring instrument is said to be good if it has good validity and reliability. Valid means being able to measure the validity of an instrument to be measured. Meanwhile, reliable means measuring instruments that give constant results. The following is the grid of the instruments used in this study:

Table 2. Instrument Grid

\begin{tabular}{|c|c|c|c|c|}
\hline No. & Data & Indicator & $\begin{array}{c}\text { Method of Data } \\
\text { Collection }\end{array}$ & $\begin{array}{c}\begin{array}{c}\text { Instrument's } \\
\text { shape }\end{array} \\
\end{array}$ \\
\hline 1. & $\begin{array}{l}\text { Mathematical } \\
\text { Connection Ability }\end{array}$ & $\begin{array}{l}\text { 1. Connection in mathematics is } \\
\text { viewed from the connection } \\
\text { between concepts and } \\
\text { mathematical topics } \\
\text { 2. Connection with daily activities }\end{array}$ & Test & Multiple Choice \\
\hline 2. & Self- Confidence & $\begin{array}{l}\text { 1. Self-Confident } \\
\text { 2. Have an optimistic attitude } \\
\text { 3. Dare to try new things } \\
\text { without fear }\end{array}$ & Non-test & Questionnaire \\
\hline
\end{tabular}


The data obtained from the study were described according to each variable, then the mean price (M), standard deviation (SD), mode (M), median (Me) were sought for each class studied. The analysis prerequisite testing that will be carried out is the normality test, homogeneity test and hypothesis testing. The normality test of the research data distribution was used to ensure that the sample came from a normally distributed population using the Kolmogorov Smirnov test statistic assisted by SPSS-PC 16.0 for windows. The test criteria is if the data has a normal distribution and the resulting significance value is greater than 0.05 . Homogeneity testing is carried out to show that two sample data come from the same population of variants where the requirements of the analysis are needed, namely that each groups of the dependent variable has the same variant. The homogeneity test used the independent t-test with SPSS-PC 16.0 for windows with the test criteria: the data has the same variant (homogeneous) if the significance value obtained is greater than 0.05 , but if the significance is less than 0.05 , the variance is different ( inhomogeneous). Hypothesis testing is used to see the effect of the ttw model on students 'mathematical connection abilities and students' self-confidence where the results of the data for the two groups (experiment and control) are normally distributed and processed using the independent sample t-test and paired sample t-test with the help of SPSS-PC. 16.0 for windows. The test criteria: if the significance value is less than 0.05 , the null hypothesis is rejected and otherwise the null hypothesis is accepted.

\section{Result and Discussion}

Based on the descriptive analysis, the following results were obtained:

Table 2. Analysis Results

\begin{tabular}{|c|c|c|c|c|}
\hline \multirow{2}{*}{ Statistics } & \multicolumn{4}{|c|}{ Variabel } \\
\hline & $\mathbf{A}_{1} \mathbf{Y}_{1}$ & $A_{1} Y_{2}$ & $A_{2} Y_{1}$ & $A_{2} Y_{2}$ \\
\hline Median & 70 & 60 & 56 & 45 \\
\hline Mean & 67,68 & 60 & 54 & 45,92 \\
\hline Modus & 70 & 60 & 56 & 45 \\
\hline Standard Deviation & 8,63 & 13,56 & 6,05 & 5,18 \\
\hline Variance & 74,46 & 184 & 36,6 & 26,79 \\
\hline Maximum Score & 80 & 90 & 60 & 59 \\
\hline Minimum Score & 50 & 40 & 40 & 37 \\
\hline Total & 1760 & 1560 & 1404 & 1194 \\
\hline
\end{tabular}

Information:

$A_{1} Y_{1}$ : The score of the mathematical connection ability test that is taught using the think talk write learning model

$\mathrm{A}_{1} \mathrm{Y}_{2}$ : Mathematical connection ability test score taught by conventional learning models

$A_{2} Y_{1}$ : Score of self-confidence that is taught using the think talk write learning model

$\mathrm{A}_{2} \mathrm{Y}_{2}$ : Score of self-confidence that is learned using conventional learning models

The results of the descriptive analysis that have been carried out on the mathematical connection ability using the think talk write learning model obtained median $=70$, mode $=70$, standard deviation $=$ 8.63 , variance $=74.46$, maximum score $=80$ and minimum score $=50$. Average - The mean of the mathematical connection ability using the think talk write learning model is 67.69 greater than using the conventional method of 60 .The results of the descriptive analysis of the mathematical connection ability carried out by the conventional method are obtained median $=60$, mode $=60$, standard deviation $=13.56$, variance $=184$, maximum score $=90$, and minimum score $=40$.

The results of descriptive analysis that have been carried out on self-confidence using the think talk write learning model obtained median $=56$, mode $=56$, standard deviation $=6.05$, variance $=36.6$, maximum score $=60$ and minimum score $=40$. Average - The average self-confidence of students who use the think talk write learning model is 54 greater than using the conventional method of 45.92 . The results of descriptive analysis that have been carried out on students' self-confidence using conventional learning models obtained median $=45$, mode $=45$, standard deviation $=5.18$, variance $=26.79$, maximum score $=$ 59 and minimum score $=37$.

Before testing the hypothesis, first the normality test and homogeneity test are carried out. The normality test of the research data distribution was used to ensure that the sample came from a normally distributed population using the Kolmogorov Smirnov test statistic assisted by SPSS-PC 16.0 for windows. Based on the results of the analysis, the Kolmogorov Smirnov significance was above 0.05, so it can be 
concluded that all data were normally distributed. Homogeneity testing is carried out to show that two sample data come from the same population of variants where the requirements of the analysis are needed, namely that each grouping of the dependent variable has the same variant. Homogeneity test will use independent t-test with SPSS-PC 16.0 for windows. Based on the homogeneity test, the results are above 0.05 , so it can be concluded that all data groups are homogeneous. The analysis prerequisite test has been fulfilled and is continued with hypothesis testing. Based on the hypothesis testing that has been done, the following results are obtained.

First, there is an influence of the think talk write learning model on the mathematical connection ability of students in class IV fractions material. Based on hypothesis testing that has been done by using the independent sample t-test it is found that sig. (2-tailed) is $0.038<0.05$ and the Paired Sample T-test sig. (2-tailed) is $0.000<0.05$. In accordance with the hypothesis, it is concluded that Ho is rejected and Ha is accepted because of the sig. (2-tailed) value $<0.05$. this means that there is a significant effect of the think talk write learning model on the mathematical connection ability of students in class IV fraction material.

The learning in experimental class is carried out by linking the real life context of students with the concept of the material. This linkage results in students being able to understand the connection between mathematics and real life so that learning becomes more meaningful and can be applied in everyday life. This happens because the experimental class uses treatment with the Think Talk Write learning model. Whereas in the control class using a conventional learning model.

Think talk write learning can certainly train student connectivity so that mathematical connection ability will be high. Rohendi in research (Muna et al., 2020) someone who has the ability to connect mathematically if there is information can evaluate it, have metacognitive awareness and has the ability to solve problems. So according to (Siagian, 2016), mathematical connections need to be learned and must be built so that mathematical connections can help students to find out the relationship of various mathematical concepts and apply them in everyday life. This is in accordance with the nature of mathematics which is closely related to the daily life of students (Ulya et al., 2016). According to (Yaniawati et al., 2019), teachers can activate previous knowledge by asking students to actively reflect, share with other friends, and write from their knowledge and experience. This can be proven by previous research conducted by (Apriyanto et al., 2018 ; Sulastri et al., 2017; Rafidah et al., 2020) stated that the use of the Think Talk Write model can improve the ability of mathematical connections as evidenced by the existence of significant differences in values for each class. Based on the explanation above, it can be concluded that there is a significant effect of the think talk write learning model on the mathematical connection ability of students in class IV fraction material.

Second, there is an influence of the think talk write learning model on the self-confidence of students in class IV fraction material. Based on the second hypothesis testing, it was obtained through independent sample t-test with sig.(2-tailed) of $0.000<0.05$ and paired sample t-test with sig.(2-tailed) of $0.000<0.05$, both of thee result can be concluded based on the hypothesis that Ho is rejected and Ha is accepted. This means that there is a significant effect of the think talk write learning model on the selfconfidence of students in class IV fraction material.

In the pretest and posttest activities, a questionnaire sheet is given which is used to measure and determine student behavior in the learning process before and after treatment. Based on the results of research on the self-confidence attitude at the pretest in each class there is still no change, but after giving different treatments the experimental class and the control class experience differences. In the experimental class, the treatment used the Think Talk Write learning model while the control class used the conventional model. Of the two classes, the posttest result of the experimental class was the highest when compared to the control class. It can be concluded that the think talk write model can affect students' self-confidence. The results of the posttest are in line with the Behavioristic Theory, namely learning theory prioritizes behavior change from the presence of a stimulus (Husamah et al., 2016).

The emergence of students' self-confidence will strengthen and motivate success, because the higher the confidence in one's own abilities, the stronger the enthusiasm for completing their work (Hendriana, 2012). The first step taken in order to build self-confidence is to understand and believe that every human being has their own strengths and weaknesses (Vandini, 2015). Self-confidence is one of the requirements for students to develop their activities and creativity in an effort to achieve optimal achievement and learning outcomes (Andayani et al., 2019). The existence of self-confidence will generate strength in students so that it can create a change and self-improvement, besides that students are free to direct their attention and self-improvement and the achievement of student learning strengths (Achdiyat et al., 2016). Research by (Radiusman et al., 2019) that Think Talk Write (TTW) learning strategy has confidence during math learning activities. Stated several research results by (Winggowati, 2018;Hayati, 
2018;Tyas et al., 2020;Lusiana et al., 2018) explained that students' confidence with the TTW method is significant so that student activity increases.

In accordance with the explanation above, it is concluded that there is a significant influence which has been shown from the results of the study that the TTW learning model has succeeded in influencing learning process so that it affects the ability of students self-confidence in class IV on fraction material.

\section{Conclusion}

To sum up, there is an influence of the think talk write learning model on the mathematical connection ability of the fourth graders on fraction material. Further, there is an influence of the think talk write learning model on their self-confidence. In this study, the researcher suggest that the think talk write learning model can be an alternative learning that can be selected for particular topics in mathematics. Teachers can use the TTW learning model because it can affect the mathematical connection ability and self-confidence of students. In addition, this study recommends that future researchers can use the learning model of Think Talk Write to teach other materials in a broader area

\section{References}

Achdiyat, M., \& Lestari, K. D. (2016). Prestasi Belajar Matematika Ditinjau Dari Kepercayaan Diri Dan Keaktifan Siswa Di Kelas. Jurnal Formatif, 6(1), 50-61. https://doi.org/10.33474/jpm.v5i2.3535

Andayani, M., \& Amir, Z. (2019). Membangun Self-Confidence Siswa melalui Pembelajaran Matematika. Jurnal Matematika, 2(2), 147-153. https://doi.org/10.24042/djm.v2i2.4279

Anita, I. W. (2014). Pengaruh Kecemasan Matematika ( Mathematics Anxiety ) Terhadap Kemampuan Koneksi Matematis Siswa SMP. Jurnal Ilmiah Program Studi Matematika STKIP Siliwangi Bandung, 3(1), 125-132. https://doi.org/10.22460/infinity.v3i1.43

Apriyanto, Royani, M., \& Atsnan, M. F. (2018). Pengaruh Rasa Ingin Tahu Terhadap Koneksi Matematis Siswa Pada Pembelajaran Trigonometri Menggunakan Model Kooperatif Tipe Think Talk Write (TTW) Di Kelas X SMA Negeri 10 Banjaramasin Tahun Pelajaran 2016-2017. Jurnal Pendidikan Matematika, 4(1), 79-87. https://doi.org/10.33654/math.v4i1.84

Haji, S., Abdullah, M. I., \& Maizora, S. (2017). Developing Students Ability Of Mathematical Connection Through Using Outdoor Mathematics Learning. Journal Of Mathematics Education, 6(1), 11-20. https://doi.org/10.22460/infinity.v6i1.234

Hamdayana, J. (2014). Model Dan Metode Pembelajaran Kreatif Dan Berkarakter. Bogor: Ghalia Indonesia.

Hasratuddin. (2013). Membangun Karakter Melalui Pembelajaran Matematika. Jurnal Pendidikan Matematika PARADIKMA, 6(2), 130-141. https://doi.org/10.24114/paradikma.v6i2.1066

Hayati, E. (2018). Implementation Think Talk Write Strategy To Level It Problem Solving Ability Mathematics And Self Confident Junior High School Students. Journal Of Innovative Mathematics Learning, 1(2), 67-74. https://doi.org/10.22460/jiml.v1i2.p162-168

Hendriana, H. (2012). Pembelajaran Matematika Humanis Dengan Metaphorical Thinking Untuk Meningkatkan Kepercayaan Diri Siswa. Jurnal Ilmiah Program Studi Matematika STKIP Siliwangi Bandung, 1(1), 90-103. https://doi.org/10.22460/infinity.v1i1.p90-103

Husamah, Pantiwati, Y., Restian, A., \& Sumarsono, P. (2016). Belajar Dan Pembelajaran. Malang: Universitas Muhammadiyah Malang.

Husna, A. (2016). Pengaruh Penerapan Strategi Pembelajaran " Think, Talk, Write " Terhadap Kemampuan Pemahaman Konsep Dan Komunikasi Matematika Siswa Kelas III SMP N Kecamatan Lembah Gumanti. Jurnal Cahaya Pendidikan, 2(1), 15-25. https://doi.org/10.33373/chypend.v2i1.602

Khoerunnisa, E., Hidayah, I., \& Wijayanti, K. (2016). Keefektifan Pembelajaran Think Talk Write Berbantuan Alat Peraga Mandiri Terhadap Komunikasi Matematis Dan Percaya Diri Siswa Kelas VII. Unnes Journal of Mathematics Education, 5(1), 47-53. https://doi.org/10.15294/ujme.v5i1.8609 
Lismawati. (2019). Pengaruh Model Pembelajaran Kooperatif Tipe Think Talk Write Bermedia Poster Terhadap Hasil Belajar Biologi. Jurnal Biotek, 7(2), 1-13. https://doi.org/10.24252/jb.v7i1.6060

Lusiana, D., \& Setyaningsih, E. (2018). Pengaruh Pembelajaran Berbasis Masalah Dengan Strategi Think Talk Write Terhadap Kemampuan Representasi Matematis Dan Self Efficary Siswa. Journal of Mathematics Education, 4(2), 23-36. https://doi.org/10.30595/alphamath.v4i2.7358

Melyana, A., \& Pujiastuti, H. (2020). Pengaruh Kepercayaan Diri Terhadap Kemampuan Berpikir Kritis Matematis Siswa SMP. Jurnal Pembelajaran Matematika Inovatif (JPMI), 3(3), 239-246. https://doi.org/10.22460/jpmi.v3i3.239-246

Muna, L. L., Kusumadewi, R. F., \& Ulia, N. (2020). Implementasi Model Pembelajaran Scramble Dengan Pendekatan Saintifik Terhadap Kemampuan Koneksi Matematis Dan Sikap Kerjasama. Jurnal $\begin{array}{llll}\text { Pengembangan Pembelajaran } & \text { Matematika 27-32. }\end{array}$ https://doi.org/10.14421/jppm.2020.021-05

N., W. P., P., D. S., \& K., A. I. (2014). Penerapan Pendekatan Pemecahan Masalah Menurut Polya Materi Persegi Dan Persegi Panjang Untuk Meningkatkan Hasil Belajar Siswa Kelas VII B SMP Negeri 10 Jember Tahun Ajaran 2012/2013. Kadikma, 5(2), 1-10. https://doi.org/10.19184/kdma.v5i2.1353

Nurapriani, F. (2016). Meningkatkan Kemampuan Komunikasi Dan Koneksi Matematik Siswa SMP Melalui Strategi Think Talk Write. Jurnal Buana Ilmu, 1(1), 45-55. https://doi.org/10.36805/bi.v1i1.97

Radiusman, Noornia, A., \& Ambarwati, L. (2019). Improving Written Communication Skills and Mathematical Disposition of Tenth Grade IPS 4 Students by Using Think-Talk- Write ( TTW ) Learning Strategy at SMAN 50 Jakarta. Jurnal Pendidikan Indonesia, 8(1), 133-140. https://doi.org/10.23887/jpi-undiksha.v8i1.14990

Rafidah, R., Purwanto, S., \& Antari, D. (2020). Pengaruh Model Pembelajaran Kooperatif Tipe Think Talk Write ( TTW ) Dengan Pendekatan Kontekstual Terhadap Kemampuan Koneksi Matematis Siswa SMP Negeri 97 Jakarta. Jurnal Riset Pembelajaran Matematika Sekolah (JRPMS), 4(2), 1-8.

Cendekia : Jurnal Pendidikan Matematika, 2(1), 105-117. https://doi.org/10.26740/jrpd.v4n2.p741-751

Siagian, M. D. (2016). Kemampuan Koneksi Matematik Dalam Pembelajaran Matematika. Journal of Mathematics Education And Science (MES), 2(1), 58-67. https://doi.org/10.30743/mes.v2i1.117

Sugiyono. (2017). Metode Penelitian Pendidikan. Bandung: Alfabeta.

Sulastri, I., Irawati, R., \& Karlina, D. A. (2017). Pengaruh Pendekatan Kontekstual Berstrategi Think Talk Write ( TTW) Terhadap Kemampuan Koneksi Matematis Siswa Pada Materi Perbandingan. Jurnal Pena Ilmiah, 2(1), 1021-1030. https://doi.org/10.17509/jpi.v2i1.11250

Supandi, S., Waluya, S. B., Rochmad, R., Suyitno, H., \& Dewi, K. (2018). Think Talk Write Model For Improving Students Abilities In Mathematical Representation. International Journal Of Instruction, 11(3), 77-90. https://doi.org/10.12973/iji.2018.1136a

Trisnawati, I., Pratiwi, W., Nurfauziah, P., \& Maya, R. (2018). Analisis Kemampuan Berpikir Kreatif Matematis Siswa SMA Kelas XI Pada Materi Trigonometri Ditinjau Dari Self Confidence. Jurnal $\begin{array}{lllll}\text { Pembelajaran Matematika Inovatif } & \text { (JPMI), } & \text { 383-394. }\end{array}$ https://doi.org/10.22460/jpmi.v1i3.383-394

Tyas, D. A., Eka, K. I., \& Wiarsih, C. (2020). Penggunaan Strategi Think, Talk, Write (TTW) Terhadap Sikap Percaya Diri Siswa Sekolah Dasar. Mukadimah : Jurnal Pendidikan, Sejarah, Dan Ilmu-Ilmu Sosial, 4, 8-15. https://doi.org/10.30743/mkd.v3i2.1520

Ulya, I. F., Irawati, R., \& Maulana. (2016). Peningkaatan Kemampuan Koneksi Matematis Dan Motivasi Belajar Siswa Menggunakan Pendekatan Kontekstual. Jurnal Pena Ilmiah, 1(1), 121-130. https://doi.org/10.23819/pi.v1i1.2940

Unaenah, E., \& Sumantri, M. S. (2019). Analisis Pemahaman Konsep Matematis Siswa Kelas 5 Sekolah Dasar Pada Materi Pecahan. Jurnal Basicedu, 3(1), 106-111. https://doi.org/10.31004/basicedu.v3i1.85 
Vandini, I. (2015). Peran Kepercayaan Diri Terhadap Prestasi Belajar Matematika Siswa. Jurnal Formatif, 5(3), 210-219. https://doi.org/10.30998/formatif.v5i3.646

Winggowati, S. (2018). Penerapan Metode Think-Talk-Write Untuk Mengembangkan Self Confidence Siswa SD. Pasundan Journal of Research In Mathematics Learning And Education, 3(1), 17-26. https://doi.org/10.23969/symmetry.v3i1.896

Yaniawati, R. P., Indrawan, R., \& Setiawan, G. (2019). Core Model On Improving Mathematical Communication And Connection , Analysis Of Students ' Mathematical Disposition. International Jurnal of Instruction, 12(4), 639-654. https://doi.org/10.29333/iji.2019.12441a 